\title{
Calibration and Validation of the DSSAT Model with Experimental Data for Three Varieties of Wheat on Different Planting Dates
}

\author{
Jalal Ahmed Elgadi \\ Misurata Agricultural Research Station, \\ ARC-LIBYA \\ $\underline{\text { Jal_gadi@hotmail.com }}$
}

https://doi.org/10.36602/jmuas.2019.v01.01.10

\begin{abstract}
The Crop Simulation Model (CERES-wheat module) of the Decision Support System for Agrotechnolgy Transfer (DSSAT) was used in this study to simulate the effect of planting date (D) on growth, development and yield of three varieties of durum wheat (Triticum turgidum L subsp. durum). The studied varieties were Cham1 (V1), Deir Alla6 (V2) and Haurani (V3). Data were obtained from a field experiment conducted for this purpose on the growing season 2015/2016 at Mushagger Agricultural Research Station Southwest Amman ( $31^{\circ} 46^{\prime} 24.7^{\prime \prime} \mathrm{N}, 35^{\circ} 47^{\prime} 47.3^{\prime \prime} \mathrm{E}, 800 \mathrm{~m}$ above sea level). First planting date (D1) was used for model calibration and the GenCalc software was applied to achieve acceptable genetic coefficient values. Calibration results showed an excellent estimation for days to anthesis, number of grains $\mathrm{m}^{-2}$, grain yield and days to physiological maturity with normalized root mean square error (nRMSE) ranged from 0 to $5.79 \%$. Tops weight, harvest index, unit grain weight (except for V3) and number of tillers $\mathrm{m}^{-2}$ were poorly simulated. Validation of the CERES-Wheat model of the DSSAT using means of observed results of D2 and D3 showed excellent simulation (nRMSE $<10 \%)$ for anthesis and maturity dates for the three examined varieties. Good prediction $(10 \leq \mathrm{nRMSE}<20 \%)$ were attained for grain yield (for V2 and V3) and for grain nitrogen percent (except for V3 which was excellent). Fair predictions $(20 \leq$ nRMSE $<30 \%)$ were recorded for grain unit weight of (V1 and V2) and tops weight of V1. Conversely, grain unit weight was poorly simulated for V3. From these results, it can be concluded that the DSSAT model can be considered as an effective tool for predicting wheat growth and yield.
\end{abstract}

Key words: DSSAT - Simulation models - CERES-Wheat - planting date - Cham 1 Deir Alla6 - Haurani

\section{INTRODUCTION}

Traditional agronomic experiments are conducted at particular points in time and space, making results site- and season-specific, time consuming and expensive (Jones et al., 2003). Therefore, using crop simulation models for predicting crop performance in different environments can be a helpful tool to attend the aims of those conventional researches in shorter time and less expenses.

Environmental modeling, particularly, the Crop Simulating Models (CSMs) can be considered as one of the modern techniques that can contribute in improving the agricultural production.

Model, in general, is a descriptive or representational imitation of a real system to improve the understanding of the behavior of that system components and how they react to changing conditions. Crop simulating models are mathematical, computer-based

114

http://www.misuratau.edu.ly/journal/jmuas/

المجلد الأول العدد الأول ديسمبر 2019 
representations of crop growth and interaction with the environment. They play an important role in scientific research and resource management (Graves et al., 2002). They have evolved into practical tools for scientists, engineers, planners, managers, and growers, who are responsible for improving management and control of such systems (Hoogenboom et al., 1992). The Decision Support System for Agrotechnology Transfer (DSSAT) is one of those decision support models, which consist of 42 crops (Jones et al., 2010). The DSSAT depends on understanding the interactions between plants, soil, weather and management. It was originally developed by an international network of scientists, cooperating in the International Benchmark Sites Network for Agrotechnology Transfer project (IBSNAT) to facilitate the application of crop models in agronomic research (IBSNAT, 1993). Its initial development was motivated by a need to integrate knowledge about soil, climate, crops, and management for making better decisions about transferring production technology from one location to others where soils and climate are different. The DSSAT (CERES-Wheat) has been extensively evaluated and validated for use in many different countries, having unique soil and climate conditions, and plant varieties. Its successful performance has been well documented making it a reliable and trusted crop model (Jones, et al., 2003). However, it should be evaluated and validated before use under arid and semi-arid conditions.

DAISY and DSSAT, out of eight tested models showed the best yield estimation with lowest root mean square error (RMSE) values and the indices of agreement were the highest (Palosuo et al 2011). The performance of the DSSAT in simulating the impact of different seeding dates and seeding rates on wheat yield based on three-year field experiments, were good with overall model efficiencies of 0.95 for growth stages, 0.85 for LAI and 0.92 for yield (Wu et al. 2013). Simulated data using the DSSAT model showed a reasonable agreement and were well matched with the reported yields with acceptable correlation coefficients and RMSE (Huffman et al. 2014), (Al-Bakri, et al. 2010) and (Al-Qerem, 2010)

The findings of Rezzoug et al. (2008) confirmed the potential use of DSSAT to predict the yield of various winter wheat cultivars, provided that the genetic coefficients are calibrated based on local field trials.

Rezzoug and Benoit (2009) assessed various wheat management strategies with DSSAT and they concluded that climate variability accounted for $95 \%$ of the overall variance of simulated yields. Sowing date recorded the most affected agronomic factor, followed by cultivar and $\mathrm{N}$ fertilizer rate, while no significant effect of plant density (Rezzoug and Benoit 2009).

Agricultural Production System Simulator (APSIM) predicted wheat crop growth and yield with more accuracy than DSSAT, thus it can be parameterized to simulate crop growth under changing climatic scenarios to select suitable genotypes, sowing time, cropping pattern, fertilizer and weed control (Ahmed and Ul-Hassan 2011),. 
Using CERES-Wheat model with temperature change scenarios for future prediction attested that wheat grain yield will be reduced in average by 12 and $31 \%$ when air temperature increased by 1.5 and $3.5^{\circ} \mathrm{C}$ respectively (Hassanein, et al. 2012).

Hussien, (2009) reported that the DSSAT-CSM can be considered as a useful tool for predicting crop growth and production under ordinary conditions, however the model need to be modified and developed to consider the impact of salinity and different cropping systems

Al-Bakri, et al. (2010) indicated that barley would be more negatively affected by the climate change scenarios compared to wheat.

The main objective of this study is to assess the performance of the DSSAT model under semiarid conditions with experimental data for different crop management practices (three varieties of durum wheat and three planting dates).

\section{Material and methods}

Data used for the model run were obtained from a field experiment conducted to study the effect of three planting dates on growth, development and yield of three varieties of durum wheat (Triticum turgidum L subsp. durum). The first planting date (D1) was on November $25^{\text {th }} 2015$, the second (D2) was on December $21^{\text {st }} 2015$ and the last (D3) was on January $19^{\text {th }} 2016$, while the examined varieties were Cham1 (V1), Deir Alla6 (V2) and Haurani (V3). The field experiment was pursued at Mushagger Agricultural Research Station Southwest Amman ( $31^{\circ} 46^{\prime} 24.7^{\prime \prime}$ N, 35 47' 47.3" E, $800 \mathrm{~m}$ above sea level). Field experiment and data collection were performed to obtain the information needed to run the DSSAT model, thus enabling comparison between observed and simulated data (IBSNAT, 1990).

The Crop Simulation Model (CERES-wheat module) of the DSSAT version 4.6.1 was used to simulate wheat crop growth, development and yield (Hoogenboom et al. 2015). The simulation was based on soil analysis, daily weather and crop management data that was collected from the field experiment. These data were entered into specific database management programs. The files in the crop models of the DSSAT are structured into input, output and experiment data files (Hoogenboom et al. 2010).

\section{Input files}

Some of the input files are dealing with the experiment, weather and soil and the others are approaching the genotypes characteristics (crop and cultivar) (Hoogenboom, et al., 2010). The standard applications of the DSSAT exist in the "Tools", "Accessories" and "Utilities" section that are presented on the left side of the main screen (Wilkens, et al., 2004). 


\section{Model calibration}

In many crop simulations models, certain coefficients are considered as inputs data to differentiate between the performance of assorted crop varieties under different environmental and management conditions (Hunt et al., 1993). These coefficients are referred to as genetic or genotype coefficients. The Genetic Coefficient Calculator v2 (GENCALC2) of the DSSAT was used to determine a best fit set of genetic coefficients for the examined varieties. The GENCALC2 is a software used for the calculation of cultivar coefficient that related to phenology phase durations, leaf development, canopy, tillers production and death, root growth and nitrogen content in plant tissues (Table 1). Cultivar calibration was done to adjust some development and growth parameters to ensure minimum differences between observed and simulated data. Thus, number of existing files such as ecotype and cultivar files were modified and others such as (A) and (T) files were created to enter all needed data. Since the studied varieties are classified as spring cultivars and they may not have vernalization requirements, P1V coefficient was set to zero in the cultivar file to launch the calibration (Ibrahim et al., 2016). As the first planting date treatment (D1) is a common sowing time of wheat in the region, it was used for model calibration to combat any possible effect of delayed planting on results.

\section{Model evaluation}

Evaluation of a model usually proceeded to compare model simulations with observed data and to determine its suitability for certain purposes (Jones et al., 2003). The model was run for the three studied wheat varieties individually under both planting dates (D2 and D3). Simulation was proceeded using CSM-CERES-Wheat model (Ritchie and Otter, 1985) by selecting the desired crop (wheat) from the crop directory tree on the main DSSAT screen. In order to evaluate the output data and for the comparison between measured and predicted results, the normalized root mean square error (nRMSE) expressed in percent was used Equations (1) and (2) (Loague and Green 1991). The predicted values are considered excellent when the nRMSE $<10 \%$, good when $10 \leq$ nRMSE $<20$, fair if $20 \leq \mathrm{nRMSE}<30 \%$ and poor when nRMSE $>30 \%$ (Jamieson et al., 1991).

$$
\begin{aligned}
& \text { RMSE }=\sqrt{\sum_{i=1}^{n} \frac{(P i-O i)^{2}}{n}} \\
& \text { nRMSE }=\text { RMSE } * \frac{100}{M}
\end{aligned}
$$

Where:

RMSE is the absolute root mean square error.

nRMSE is normalized root mean square error expressed in percent of the relative difference between simulated and observed values.

$P_{i}$ and $O_{i}$ indicate predicted and observed values for the studied variable, respectively, $n$ is number of used observations and $M$ is the mean of the observed variable. 
Table (1) Genetic coefficient definitions

\begin{tabular}{|l|l|}
\hline Coefficient & Definition \\
\hline ECO\# & Ecotype code for the specified cultivar to be used in ECO file \\
\hline P1V & Days, optimum vernalizing temperature required for vernalization \\
\hline P1D & Photoperiod response (\% reduction in rate/10 h drop in pp) \\
\hline P5 & Grain filling (excluding lag) phase duration $\left({ }^{\circ} \mathrm{C} . d\right)$ \\
\hline G1 & Kernel number per unit canopy weight at anthesis (\#/g) \\
\hline G2 & Standard kernel size under optimum conditions $(\mathrm{mg})$ \\
\hline G3 & $\begin{array}{l}\text { Standard non-stressed mature tiller wt (including grain) }(\mathrm{g} \text { dry } \\
\text { wt) }\end{array}$ \\
\hline PHINT & Interval between successive leaf tip appearances $\left({ }^{\circ} \mathrm{C} . d\right)$ \\
\hline
\end{tabular}

Source: (Hoogenboom et al., 2010).

\section{Results}

\section{Model calibration for cultivar genetic coefficients estimation}

A set of genetic coefficients were obtained from the GenCalc for the studied cultivars according to the lowest values of nRMSE (\%). Table (2) shows values of both, original coefficients with which the calibration were initiated and the generated values that resulted from the software.

Table (2) Original and calculated values of genetic coefficients as resulted by GenCalc calculator

\begin{tabular}{|l|l|l|l|l|l|l|l|l|l|}
\hline & $\begin{array}{l}\text { VAR. } \\
\text { Name }\end{array}$ & $\begin{array}{l}\text { ECO } \\
\text { code }\end{array}$ & $\begin{array}{l}\text { P1V } \\
(\text { V day })\end{array}$ & $\begin{array}{l}\text { P1D } \\
(\% / 10 \mathrm{~h} \\
)\end{array}$ & $\begin{array}{l}\text { P5 } \\
\left({ }^{\circ} \mathrm{C} . \mathrm{d}\right. \\
)\end{array}$ & $\begin{array}{l}\text { G1 } \\
(\# / \mathrm{g})\end{array}$ & $\begin{array}{l}\text { G2 } \\
(\mathrm{mg})\end{array}$ & $\begin{array}{l}\text { G3 } \\
(\mathrm{g})\end{array}$ & $\begin{array}{l}\text { PHIN } \\
\mathbf{T} \\
\left({ }^{\circ} \mathrm{C} . \mathrm{d}\right)\end{array}$ \\
\hline Original & NEWTON & $\begin{array}{l}\text { USWH0 } \\
1\end{array}$ & 0 & 75 & 500 & 25 & 30 & 2 & 95 \\
\hline \multirow{5}{*}{$\begin{array}{l}\text { Calculate } \\
\mathrm{d}\end{array}$} & CHAM1 & $\begin{array}{l}\text { USWH0 } \\
1\end{array}$ & 0.9 & 78.75 & 556.7 & 11.51 & 25.62 & 6.421 & 119 \\
\cline { 2 - 10 } & $\begin{array}{l}\text { DEIR } \\
\text { ALLA6 }\end{array}$ & $\begin{array}{l}\text { USWH0 } \\
1\end{array}$ & 0.6 & 90.75 & 517.9 & 11.16 & 32.9 & 5.04 & 119 \\
\cline { 2 - 10 } & $\begin{array}{l}\text { HAURAN } \\
\mathrm{I}\end{array}$ & $\begin{array}{l}\text { USWH0 } \\
1\end{array}$ & 0.15 & 88.36 & 495.2 & 10.67 & 31.16 & 2.571 & 104.6 \\
\hline
\end{tabular}


Table (3) shows model calibration resulted from GenCalC2 software with first planting date treatment. Excellent predictions were achieved by the software for the three studied cultivars for the traits: days to anthesis, days to maturity, grain number $\mathrm{m}^{-2}$ and grain yield. Values of nRMSE for these traits ranged from 0 to $6.67 \%$, indicated that the different between observed and simulated values were negligible. Additionally, similar values were resulted for grain nitrogen content and grain unit weight for the cultivar Haurani (nRMSE $=0$ for both traits).

Good simulation was attained only for grain nitrogen content for the cultivar Cham 1 $(\mathrm{nRMSE}=15 \%)$. Harvest index, grain nitrogen content and grain unit weight were fairly predicted for the cultivar Deir Alla 6, nRMSE values were 26.67, 21.05 and $25.0 \%$, respectively. Conversely, the calibration showed poor predictions (nRMSE $>30 \%$ ) for tops weight (for all tested cultivars), harvest index (for Cham 1 and Haurani) and for grain unit weight (for Cham 1).

Table (3) Simulated and observed data and calibration results as calculated using GenCalc2

\begin{tabular}{|c|c|c|c|c|c|c|c|c|c|}
\hline \multirow{3}{*}{ Parameter } & \multicolumn{9}{|c|}{ Cultivar } \\
\hline & \multicolumn{3}{|c|}{ CHAM 1} & \multicolumn{3}{|c|}{ DEIR ALLA 6} & \multicolumn{3}{|c|}{ HAURANI } \\
\hline & $\begin{array}{l}\text { SIM } \\
\text { U }\end{array}$ & $\begin{array}{l}\text { OBS } \\
\text { E }\end{array}$ & $\begin{array}{l}\text { nRMSE } \\
(\%)\end{array}$ & SIMU & OBSE & $\begin{array}{l}\text { nRMSE } \\
(\%)\end{array}$ & $\begin{array}{l}\text { SIM } \\
\text { U }\end{array}$ & OBS & $\begin{array}{l}\text { nRMSE } \\
(\%)\end{array}$ \\
\hline $\begin{array}{ll}\text { Days } & \text { to } \\
\text { anthesis } & \end{array}$ & 138 & 138 & $0.0(\mathrm{E})$ & 147 & 147 & $0.0(\mathrm{E})$ & 144 & 144 & $0.0(\mathrm{E})$ \\
\hline $\begin{array}{ll}\text { Tops } & \text { wt. } \\
(\mathrm{kg} / \mathrm{ha}) & \\
\end{array}$ & 15053 & 7992 & $88.35(\mathrm{P})$ & 14228 & 10293 & $38.23(\mathrm{P})$ & 14209 & 9791 & $45.12(\mathrm{P})$ \\
\hline Grain no. $\mathrm{m}^{-2}$ & 10473 & 11021 & $4.97(\mathrm{E})$ & 9527 & 9944 & $4.19(\mathrm{E})$ & 8822 & 8535 & $3.36(\mathrm{E})$ \\
\hline Harvest index & 0.166 & 0.31 & $46.45(\mathrm{P})$ & 0.22 & 0.3 & $26.67(\mathrm{~F})$ & 0.189 & 0.27 & $30.00(\mathrm{P})$ \\
\hline Grain N (\%) & 2.3 & 2 & $15.00(\mathrm{G})$ & 2.3 & 1.9 & $21.05(\mathrm{~F})$ & 2.3 & 2.3 & $0.0(\mathrm{E})$ \\
\hline $\begin{array}{ll}\text { Grain } & \text { Yield } \\
\text { (kg/ha) } & \\
\end{array}$ & 2503 & 2501 & $0.08(\mathrm{E})$ & 3134 & 3131 & $0.10(\mathrm{E})$ & 2691 & 2691 & $0.0(\mathrm{E})$ \\
\hline $\begin{array}{ll}\begin{array}{l}\text { Grain } \\
(\text { g/grain) }\end{array} & \text { wt. } \\
\end{array}$ & 0.024 & 0.036 & $33.33(\mathrm{P})$ & 0.033 & 0.044 & $25.00(\mathrm{~F})$ & 0.031 & 0.031 & $0.0(\mathrm{E})$ \\
\hline Maturity day & 179 & 190 & $5.79(\mathrm{E})$ & 182 & 193 & $5.70(\mathrm{E})$ & 179 & 192 & $6.77(\mathrm{E})$ \\
\hline Tiller no \#/m2 & 499 & 303 & $64.69(\mathrm{P})$ & 527 & 286 & $84.27(\mathrm{P})$ & 553 & 325 & $70.15(\mathrm{P})$ \\
\hline
\end{tabular}

(E) means excellent, $(\mathrm{G})$ good, $(\mathrm{F})$ fair and $(\mathrm{P})$ poor

\section{Model validation}

Validation was conducted to assess the performance of the model under certain environmental and management conditions. Variable results were obtained from the model run among cultivars for the same parameter. Figures (1, 2 and 3) and Table (4) illustrate differences between simulated data resulted from DSSAT and that observed from field experiment (average of D2 and D3) for the following traits: 


\subsection{Grain yield}

Good simulation values of grain yield was predicted by the model for V2 and for V3 when compared to observed yield that recorded nRMSE values of 16.42 and $16.97 \%$, respectively. However, poor grain yield prediction was underestimated for V1 versus field measurements with a value of nRMSE of $42.25 \%$ Figure (1).

\subsection{Anthesis day}

Simulation results for the number of days from planting to anthesis showed excellent prediction for the three examined varieties compared to observed values obtained from field experiment, The model predicted this trait for V1, V2 and V3 having nRMSE of 3.9, 1.36 and $2.16 \%$, respectively Figure (2).

\subsection{Physiological maturity day}

CERES-Wheat model had excellently simulated the days from planting to physiological maturity for all examined varieties V1, V2 and V3 with nRMSE values 5.57, 4.18 and $5.47 \%$, respectively Figure (2).

\subsection{Tops weight}

Simulation of Tops weight at maturity (above ground biomass) was fair for V1 when compared with measured data that recorded $26.78 \%$ nRMSE, while it was poorly overestimated for the other two varieties V2 and V3 with nRMSE 33.08 and $57.29 \%$, respectively Figure (3).

\subsection{Number of grains per square meter}

Results of this trait revealed poorly underestimated prediction for V1 with nRMSE $40.61 \%$. However, the simulation was good for V2 and excellent for V3 with nRMSE values of $12.96 \%$ and $7.55 \%$, respectively Table (4)

\subsection{Harvest index}

As shown in (Table 4), this trait was underestimated poorly for V1 (0.175) and V2 (0.223) compared to their observed values (0.365) and (0.33), respectively while it was fairly predicted for V3 (0.197) compared to measured index of 0.275. Mainwhile, the values of nRMSE between simulated and observed harvest index for V1, V2 and V3 were 52.3, 33.0 and 29.1, respectively. 


\subsection{Grain nitrogen content}

The prediction of grain nitrogen percent resulted from the model (Table 4), exhibited good simulation for V1 and V2 $(2.2 \% \mathrm{~N}$ for the both) compared to $1.9 \%$ measured values having nRMSE of 16.63 and $15.79 \%$, respectively, however the simulation was excellent for V3, which recorded nRMSE value of $3.23 \%$ containing $2.2 \%$ nitrogen in both, simulated and observed records.

\subsection{Single grain weight}

Simulation of grain weight was fair for V1 and V2 when compared to measured weight having nRMSE of 29.73 and $25 \%$, respectively. However, for V3 the simulated grain weight was good that recorded $0.037 \mathrm{~g}$ per grain versus observed weight of $0.033 \mathrm{~g}$ and nRMSE was $18.92 \%$ Table (4).

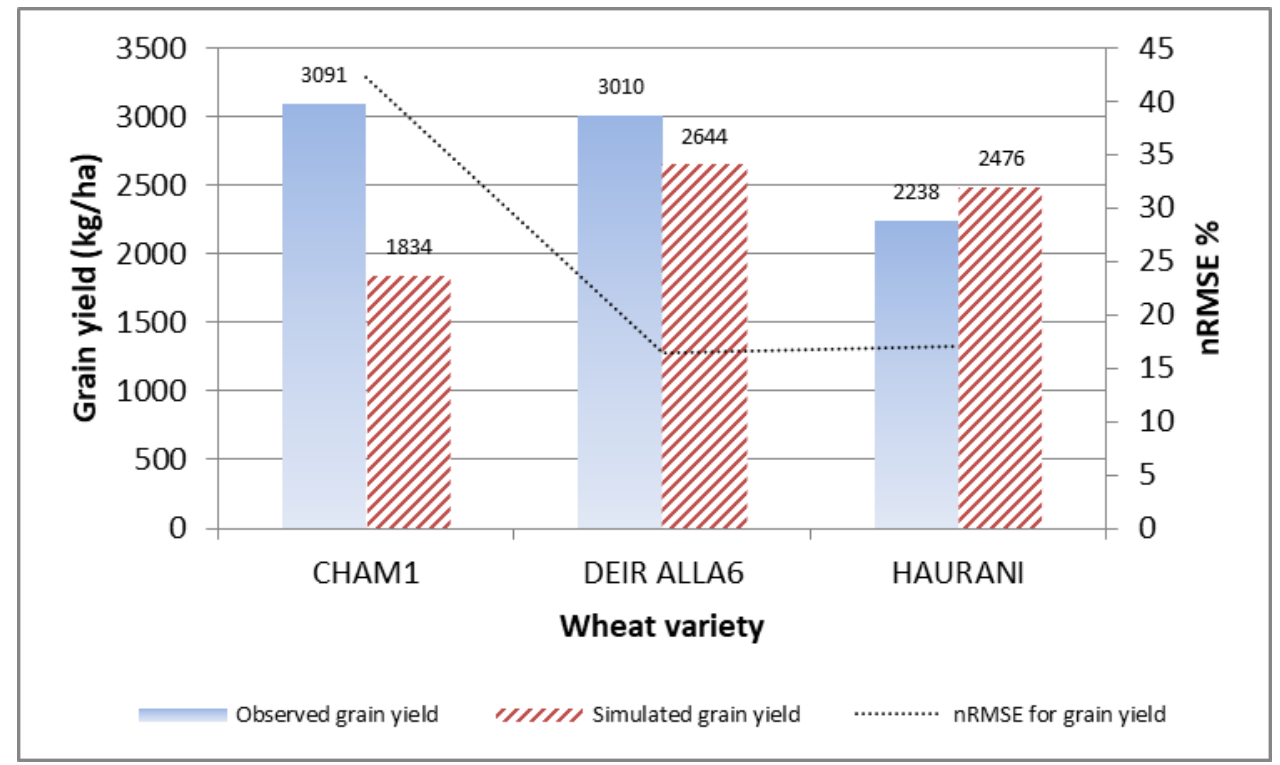

Figure. (1) Observed and simulated grain yield and the nRMSE for the studied varieties

Table (4) Observed data from field experiment and predicted values resulted from CERES-Wheat model for some variables and some statistical indices.

\begin{tabular}{|l|l|l|l|l|l|l|}
\hline Variable Name & $\begin{array}{l}\text { Crop } \\
\text { variety }\end{array}$ & Observed & Simulated & RMSE & $\begin{array}{l}\text { nRMSE } \\
\%\end{array}$ & $\begin{array}{l}\text { Simulation } \\
\text { level }\end{array}$ \\
\hline No. of Grain $\mathrm{m}^{-2}$ & V1 & 11567 & 7164 & $4697.1(-)$ & 40.61 & Poor \\
\hline & V2 & 9118 & 8035 & $1181.2(-)$ & 12.96 & Good \\
\hline & V3 & 8058 & 7936 & $608.6(-)$ & 7.55 & Excellent \\
\hline Harvest index & V1 & 0.365 & 0.175 & $0.191(-)$ & 52.33 & Poor \\
\hline & V2 & 0.33 & 0.223 & $0.109(-)$ & 33.03 & Poor \\
\hline
\end{tabular}




\begin{tabular}{|l|l|l|l|l|l|l|}
\hline & V3 & 0.275 & 0.197 & $0.080(-)$ & 29.09 & Fair \\
\hline Grain N \% & V1 & 1.9 & 2.2 & $0.316(+)$ & 16.63 & Good \\
\hline & V2 & 1.9 & 2.2 & $0.300(+)$ & 15.79 & Good \\
\hline & V3 & 2.2 & 2.2 & 0.071 & 3.23 & Excellent \\
\hline $\begin{array}{l}\text { Grain Weight } \\
\text { (g/grain) }\end{array}$ & V1 & 0.037 & 0.026 & $0.011(-)$ & 29.73 & Fair \\
\hline & V2 & 0.044 & 0.033 & $0.011(-)$ & 25.00 & Fair \\
\hline & V3 & 0.037 & 0.031 & $0.007(-)$ & 18.92 & Good \\
\hline
\end{tabular}

$(-)$ under-simulated, $(+)=$ over-simulated

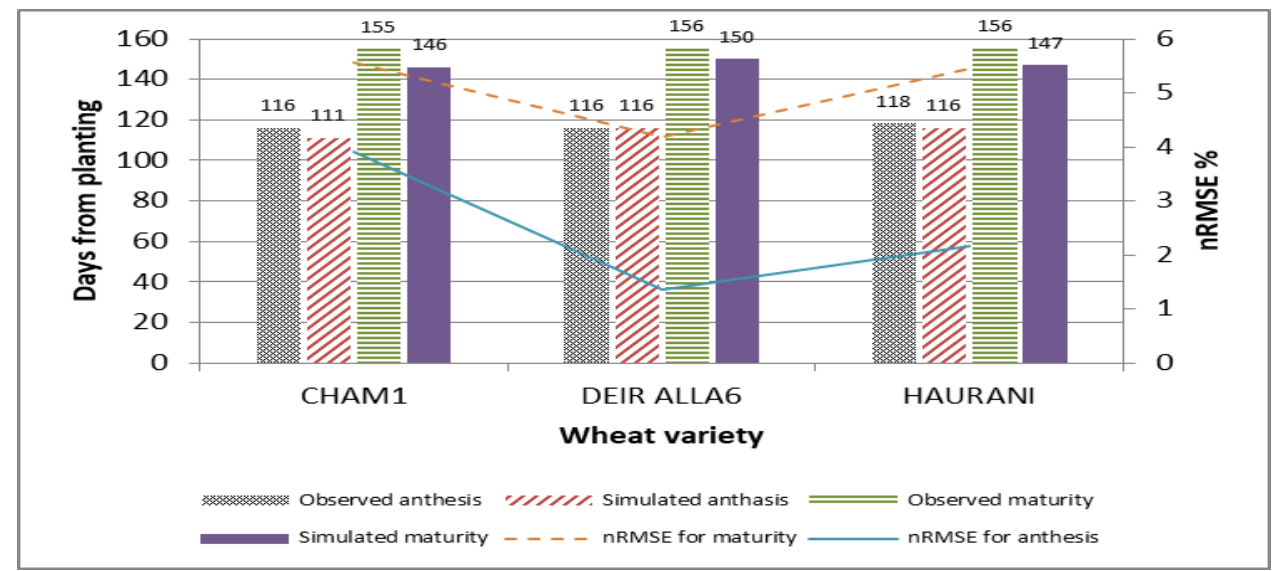

Figure. (2) Observed and simulated results for days to anthesis and days to physiological maturity and the nRMSE for the studied varieties

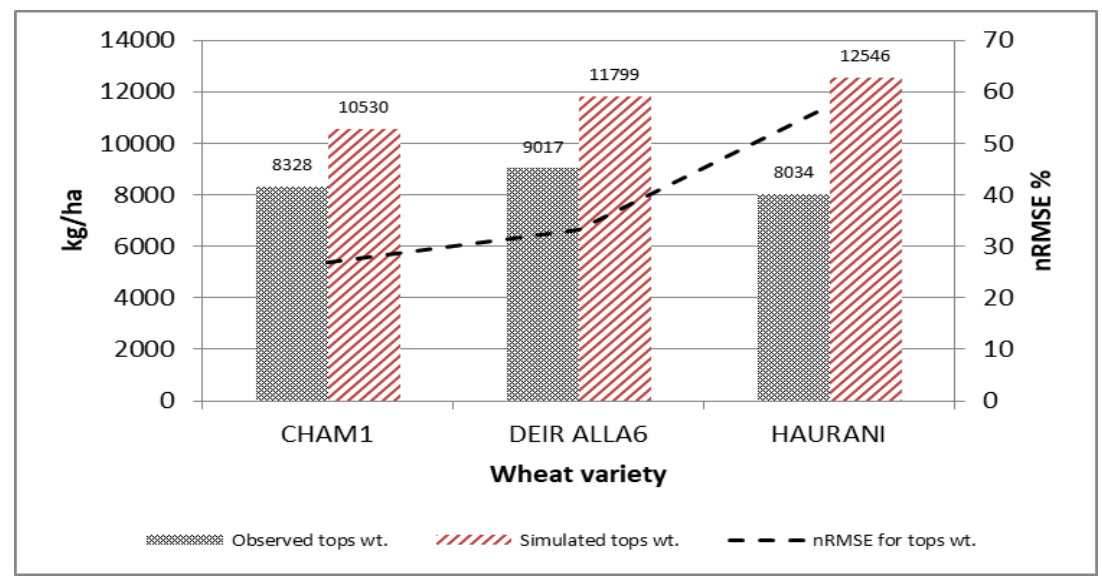

Figure. (3) Results of observed and simulated tops weight for the studied varieties 


\section{Discussion}

Results obtained from the model calibration showed excellent prediction for many tested traits of the studied cultivars. These results are in line with Maldonado-Ibarra et al. (2015) who investigated the genetic coefficients of three spring wheat varieties using the DSSAT model and they reported that nRMSE values for days to anthesis ranged from 3.5 to $9.7 \%$ according to the variety. They also indicated that acceptable calibration results can be obtained using the DSSAT model and good predictions of yields for the studied varieties were achieved, which support the findings of this study. The reason of this accuracy could be related to the robust performance of the GenCalc software in calculating the genetic coefficients beside the capability of the CERES-Wheat in estimating these traits (Ibrahim et al. 2016). On the other hand, the simulations resulted from the validation of the model were varied from excellent to poor prediction among the simulated traits and within the tested cultivars. The poor simulations, which indicate the high differences between predicted and observed values may be attributed to: (i) errors related to some initial genetic coefficients particularly, those responsible for traits that poorly simulated (Xiong et al. 2008), (ii) errors may be due to the low number of experimental treatments, which may affect the reliability of the means in addition to relaying on single season observations as data input (Hoogenboom, et al. 2012) and (iii) could be due to the weakness of the model in predicting some traits (Palosuo, et al. 2011). The achieved results can be considered as an acceptable indicator to relay on the DSSAT model in predicting phynological stages and yield and yield components of wheat. These results are matched the findings of Bahram, et al. (2014) and Pal, et al., (2015) who confirmed the robustness of the CERES-Wheat model in simulating wheat grain yield that they stated very well model simulation results with nRMSE value of $11.8 \%$ between predicted and observed grain yield.

\section{Conclusion and recommendations}

Generally, DSSAT model can be considered as an effective tool for predicting crop growth and yield and therefore as decision supporter. The DSSAT model was capable of simulating phenological stages (anthesis and physiological maturity days) perfictly. Satisfactory predictions can be obtained by the model for grain yield, grain nitrogen content and grain unit weight. Cultivar genetic charactarestics can affect the performance of the model. In accordance to this study, The following recommendations could be considered:

- This work should be repeated with different environmental and management scinarios, multi-location and multi-season observations to obtain more applicable data for mor dependable evaluation

- Other croping system models should be compared to the DSSAT model using experimental data from different regions of arid and semiarid zones. 


\section{References}

Al-Bakri, J., A. Suleiman, F. Abdulla and J. Ayad. (2011). Potential impact of climate change on rainfed agriculture of a semi-arid basin in Jordan. Physics and Chemistry of the Earth. 36 (5/6): p 125-134.

Alexandratos, N. and J. Bruinsma. (2012), World agriculture towards 2030/2050: the 2012 revision. Food and Agriculture Organization FAO Working paper No. 12-03. Rome,

AL-Qerem, R. (2010). Assessing and modeling tomato yield and water saving under water deficit in Jordan Valley, Unpublished master thesis, University of Jordan, Amman, Jordan.

Bahram, A., G. Hoogenboom, M. Bannayan, M. Shirali, and B. Andarzian. (2014). Determining optimum sowing date of wheat using CSM-CERES-Wheat model, Journal of the Saudi Society of Agricultural Sciences, King Saud University, (14): p 189-199.

Hassanein, M.K., M. Elsayed, and M. Khalil. (2012). Impact of sowing date, cultivar, irrigation regimes and location on bread wheat production in Egypt under climate change condition. Nature and science 10 (12): p 141-150.

Hoogenboom, G., J.W. Jones, P.W. Wilkens, C.H. Porter, K.J. Boote, L.A. Hunt, U. Singh, J.I. Lizaso, J.W. White, O. Uryasev, R. Ogoshi, J. Koo, V. Shelia, and G.Y. Tsuji, (2015) Decision Support System for Agrotechnology Transfer (DSSAT) Version 4.6 (www.DSSAT.net). DSSAT Foundation, Prosser, Washington USA.

Hoogenboom, G., J. Jones, P. Traore and K. Boote (2012), Experiments and Data for Model Evaluation and Application in: Kihara, J., Fatondji, D., Jones, J., Hoogenboom,

G., Tabo, R. and Bationo, A. (2010), Improving soil fertility recommendations in Africa using the Decision Support System for Agrotechnology Transfer (DSSAT) Dordrecht Springer Science \& Business Media: P 9-18.

Hoogenboom, G., J. Jones, C. Porter, P. Wilkens, K. Boote, L. Hunt and G. Tsuji (2010) Decision Support System for Agrotechnology Transfer (DSSAT) Version 4.5 Volume 1: Overview. University of Hawaii, Honolulu, HI.

Hoogenboom, G., W. Jones, and K. Boote (1992). Modeling growth, development, and yield of grain legumes using Soygro, Pnutgro, and Beangro: A review. American Society of Agricultural Engineers 35(6).

Huffman, T., B. Qian, R. De Jong, J. Liu, H. Wang, B. McConkey, T. Brierley and J. Yang, (2014). Upscaling modelled crop yields to regional scale: A case study using

124

http://www.misuratau.edu.ly/journal/jmuas/

المجلد الأول العدد الأول ديسمبر 2019 
عدد خاص بالأوراق العلمية المقدمة للمؤنمر العلمي الأول للعلوم الزراعية اللعلوم إنتاج نباتي (5-6 أكتوبر 2019)

DSSAT for spring wheat on the Canadian prairies. Canadian Journal of Soil Science, 95(1): p 49-61.

Hunt, L., S. Pararajaysingham, J. Jones, G. Hoogenboom, D. Imamura and R. Ogoshi, (1993). GENCALC:Software to facilitate the use of crop models for analyzing field experiments. Agronomy J. 85(5): p 1090-1094.

Hussien, M. (2009). Response of soybean and pearl millet grown in row intercropping system under different soil salinity and irrigation levels, PhD Dissertation, University of Jordan, Amman, Jordan.

Ibrahim, O., A. Gaafar, A.Wali, M. Tawfik M. and El-Nahas, (2016). Estimating cultivar coefficients of a spring wheat using GenCalc and GLUE in DSSAT, Journal of Agronomy. 10: p 130-135.

IBSNAT, International Benchmark Sites Network for Agrotechnology Transfer (1990). Technical report 2, Field and laboratory methods for the collection of the IBSNAT minimum dataset. Department of Agronomy and Soil Science, Hawaii Institute of Tropical Agriculture and Human Resources, University of Hawaii.

IBSNAT, International Benchmark Sites Network for Agrotechnology Transfer. (1993), The decade. Department of Agronomy and Soil Science, College of Tropical Agriculture and Human Resources, University of Hawaii, Honolulu, Hi.

Jones, J., G. Hoogenboom, C. Porter, K. Boote, W. Batchelor, L. Hunt, P. Wilkens, U. Singh, A. Gijsman and J. Ritchie. (2003). The DSSAT cropping system model European journal of Agronomy 18: p 235-265.

Jones, J., G. Hoogenboom, P. Wilkens, C. Porter and G. Tsuji. (2010). Decision Support System for Agrotechnology Transfer Version 4.0. Volume 4 DSSAT v4.5: Crop model documentation. University of Hawaii. Honolulu. HI.

Loague, K. and R. Green. (1991). Statistical and graphical methods for evaluating solute transport models: Overview and Application, Journal of Contaminant Hydrology. 7(12): p 51-73.

Maldonado-Ibarra, I., G. Rodriguez and D. Rosales. (2015). Determination of genetic coefficients of three spring wheat varieties under a Mediterranean environment applying the DSSAT model, Chilean Journal of Agricultural Research. 75(4): 418-424.

Mukhtar, A. and H. Fayyaz. (2011). APSIM and DSSAT models as decision support tools. 19th International Congress on modeling and simulation, Perth, Australia, 12-16 Dec. 2011 http://mssanz.org.au/modsim2011. 
Pal, R., K. Rawat, J. Singh and N. Murty, (2015). Evaluation of CSM-CERES-Wheat in simulating wheat yield and its attributes with different sowing environments in Tarai region of Uttarakhand, Journal of Applied and Natural Science 7 (1): p 404-409.

Palosuo, T., C. Kersebaum, C. Angulo, P. Hlavinka, M. Moriondo, J. Olesen, R. Patil, F. Rugetg, C. Rumbaur, J. Takac, M. Trnka, M. Bindii, B. Caldag, F. Ewert, R. Ferrise, W. Mirschel, L. Saylan, B. Siska and R. Rotter. (2011). Simulation of winter wheat yield and its variability in different climates of Europe: A comparison of eight crop growth models, European Journal of Agronomy 35: p 103-114.

Rezzoug, W. and G. Benoit. (2009). Assessing wheat management options in the Tiaret region of Algeria with the DSSAT model Dirasat, Agricultural Sciences, 36 (2).

Rezzoug, W., G. Benoit, A. Suleiman and K. Benabdeli. (2008). Application and evaluation of the DSSAT-wheat in the Tiaret region of Algeria. African Journal of Agricultural Research 3 (4): p 284-296.

Ritchie, J., S. Otter. (1985). Description and performance of CERES-Wheat: a useroriented wheat yield model. In: ARS Wheat Yield Project. ARS-38: p 159-175.

Wilkens, P., G. Hoogenboom, C. Porter, J. Jones, and O. Uryasev. (2004). Decision Support System for Agrotechnology Transfer Version 4.0. Volume 2 DSSAT v4: Data Management and Analysis Tools. University of Hawaii. Honolulu. HI.

Xiong, W., D. Conway, I. Holman. and E. Lin. (2008). Evaluation of CERES-Wheat simulation of wheat production in China, Agronomy Journal 100(6): p 1720-1728. 


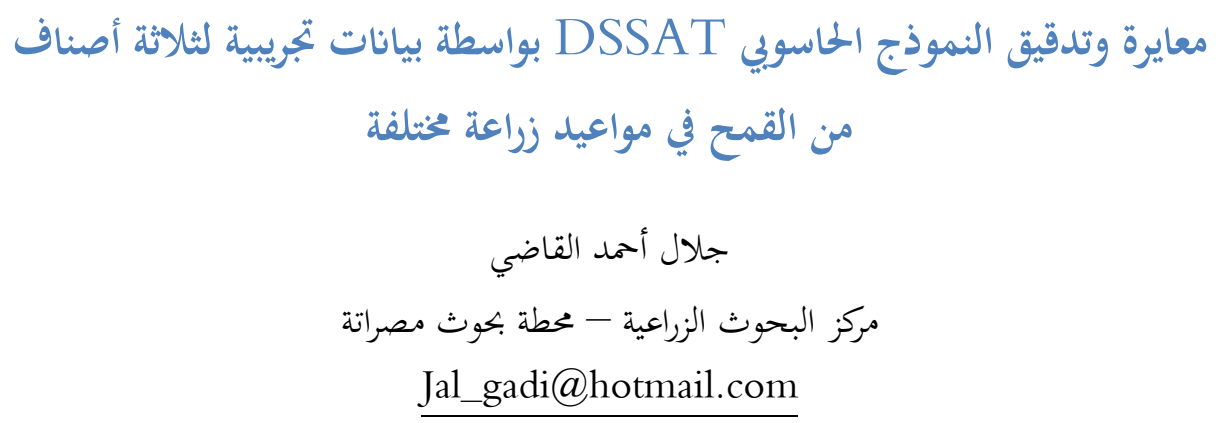

https://doi.org/10.36602/jmuas.2019.v01.01.10

قدف هذه الورقة لمعايرة نظام دعم القرارات لنقل التقنيات الزراعية (DSSAT) في التنبؤ بتأثير مواعيد الزراعة على نمو وتطور وإنتاجية ثلاثة أصناف من محصول القمح الصلب (Triticum turgidum L. Var. durum ) وهذه الأصناف هي: شام 1, ديرعلاك6 و و حوراني، البيانات المستخدمة في معايرة وتقييم هذا النموذج تم الحصول عليها من نتائج بتربة حقلية نفذت لهذا الغرض خلال الموسم الزراعي

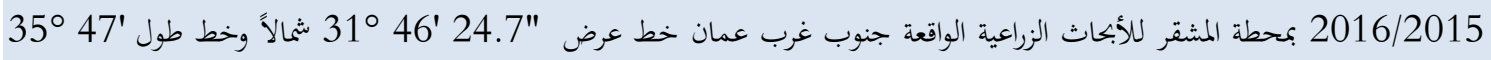

$$
\text { "47.3 شرقاً وعلى ارتفاع } 800 \text { م عن مستوى سطح البحر. }
$$

إن استخدام البرنامج GenCalc (الخاص بحساب الصفات الوراثية) أعطى نتائج مقبولة لقيم العوامل الوراثية للمحصول مما يسر عملية معايرة

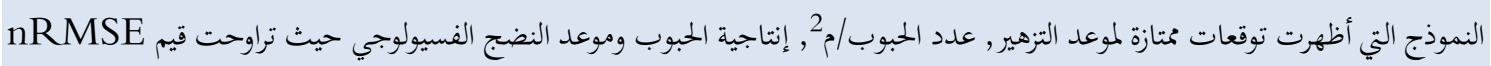

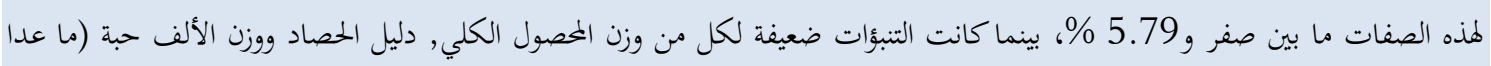
للصنف حوراني التي كانت توقعاته متازة), كذلك بالنسبة لعدد الأفرع/م² والوزن الخضري ( سيقان + أوراق). أظهرت نتائج تقييم النظام الحاسوبي CERES-Wheat الملحق بال DSSAT عند استخدام البيانات الحقلية لمتوسط معاملتي موعد الزراعة الثاني والثالث وبمقارنة القيم الواقعية مع القيم الناتحة من النموذج فقد كان مستوى التوقعات ممتازاً لموعدي التزهير والنضج في جميع

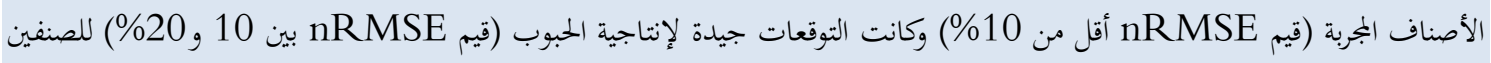
ديرعللا6 وحوراني، وكذلك لنسبة النيتروجين في الحبوب (ماعدا للصنف حوراني)، سجلت تقديرات النموذج مستوى مقبول (قيم

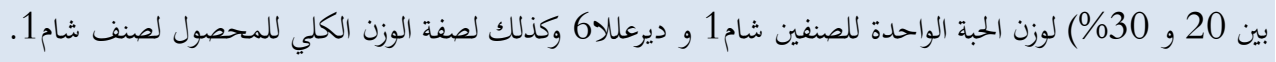

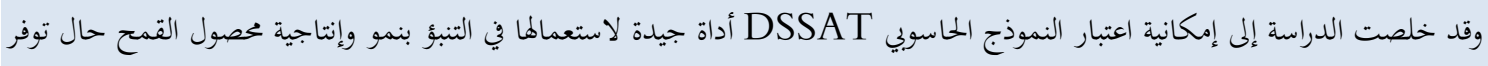
البيانات المطلوبة. 